\title{
Observations on Apis cerana colonies surviving from Thai Sacbrood Virus infestation
}

\author{
LR Verma *, BS Rana **, S Verma \\ HP University, Department of Bio-Sciences, Shimla 5, India
}

(Received 25 November 1989; accepted 9 January 1990)

\begin{abstract}
Summary - Apis cerana colonies, surviving from Thai Sacbrood Virus disease, showed disease symptoms earlier, with more severity and with a greater reduction in prolificness in parent than in daughter, colonies. Parent colonies also took longer to recover from infection and showed abnormal behaviour compared to daughters colonies. No such symptoms were observed in control $A$ cerana and $A$ mellifera (virus fed) colonies.
\end{abstract}

Apis cerana / Thai Sacbrood Virus / virus disease / sacbrood

\section{INTRODUCTION}

Sacbrood Virus disease in the Western honey bee, Apis mellifera L, has been known since 1964 (Bailey et al, 1964). However, in $A$ cerana, this virus disease was first reported in 1976 in Thailand. Due to variations in viral physico-chemical and serological properties, the present virus was named Thai Sacbrood Virus (TSBV). to distinguish it from Sacbrood Virus of $\boldsymbol{A}$ mellifera (Bailey et al, 1982). TSBV spread to the entire region of Hindu Kush Himalayas: Burma, Nepal and India (fig 1). More than $95 \%$ of the colonies were killed (Rana et al, 1986), particularly in the temperate regions where this disease is most widespread.

We confirmed the presence of Thai Sacbrood Virus in diseased colonies of $\boldsymbol{A}$ cerana in Northern India by conducting electron microscopic and serological studies in our laboratory (Rana et al, 1986, 1987). Further confirmation was made by sending paper squashes of diseased larvae to Rothamsted Experimental Station, England. Various preventive or control measures recommended for Sacbrood disease in $A$ mellifera have proved unsuccessful in $A$ cerana (Rana et al, 1986). One of the significant features of this disease, is that only about $5 \%$ of the colonies in affected areas survived infection. We now report experiments and observations on Thai Sacbrood Virus infection in surviving colonies by feeding them freshly purified virus suspensions in sugar syrup.

\section{MATERIALS AND METHODS}

In the screening experiments, colonies of $\boldsymbol{A}$ cerana (about $5 \%$ ) which recovered from infection

\footnotetext{
* Correspondence and reprints

** Present address: Department of Entomology and Apiculture, UHF, Nauni, Solan, India
} 
of Thai Sacbrood Virus disease, were collected from affected apiaries of Himachal Pradesh (India). The colonies were maintained in an apiary of Himachal Pradesh University, Shimla (India). From these, 25 colonies (of approximately equal strength and brood conditions) were fed with freshly purified virus suspensions in sugar syrup and 5 were kept as controls by feedings of pure sugar syrup only. Control colonies were kept 3$4 \mathrm{~km}$ away from other experimental colonies. Thai Sacbrood Virus was isolated from the diseased brood of $A$ cerana in 0.5 mol. -1 $^{-1}$, potassium phosphate buffer ( $\mathrm{pH} 0.8$ ) containing $0.02 \%$ DIECA and 0.02 mol. $^{-1}$ EDTA plus $10 \%$ $\mathrm{C} \mathrm{Cl}_{4}$, and purified by differential centrifugation at $8000 \mathrm{~g}$ and $100000 \mathrm{~g}$ (Bailey et al, 1982). In this way, $100 \mathrm{~g}$ of brood was converted into 25 $\mathrm{ml}$ of virus suspension in distilled water. This was fed, in $50 \%$ sugar syrup, in the ratio of 1200 to each colony in 1 set of experiments. Serological identification of TSBV from experimental colonies was made according to the method of Rana et al (1986).

Further experiments were conducted by producing 1 daughter queen or colony from each parent colony. These daughter queens (1st generation) were allowed to mate with the drone bees of the surviving colonies in an isolated mating yard. The 2nd generation queen bees were produced from the 1st generation queens (again 1 queen from each colony) and the mating of these queens was allowed to take place with the drones produced by 1st generation colonies. Similarly, experiments were repeated up to the 5th generation and each generation was tested for resistance by feeding freshly purified virus suspensions in sugar syrup. In 1 year, 2 generations were reared and each generation was treated once. Feeding treatments were given 1 month after the mating of the queen (new generation), when colonies had healthy brood of all stages. Finally, 5th generation colonies were multiplied by adopting mass queen rearing technique.

For each generation, data such as appearance of symptoms, degree of infection and recovery period were noted after feeding the freshly purified virus suspension. The incubation period was assessed by the appearance of typical symptoms of the disease in larvae and prepupae after feeding. The degree of infection was estimated by measuring the total brood and infected brood of the treated colony, with the help of a grid, and is expressed in terms of percentage of infection (\%). Total brood area in the experimental colonies varied from $1300-2350$ $\mathrm{cm}^{2}$. Each experimental colony was inspected every 3rd day to assess the degree of infection, and observations were taken until there were no infected larvae. The recovery period was estimated by taking the duration between the appearance of disease symptoms (after feeding the virus suspension) and the disappearance of infection (no diseased larvae). For this purpose, colonies were inspected throughout the life of a generation (after feeding the virus). Similarly, the effect of infection is also studied with regard to queen prolificness (egg laying rate per d). Prolificness was recorded (before and after feeding the virus) at weekly intervals, with the help of a wire grid, and is expressed in terms of percentage reduction in prolificness (\%).

The behaviour of these colonies, with regard to coverage of brood by nurse bees, tendency to abscond, aggressiveness and efficiency in cleaning out the diseased brood, was studied qualitatively. Observations were taken on these parameters every 3rd day. We also repeated the above experiments of feeding freshly purified virus to healthy $A$ mellifera colonies, but no symptoms of the disease appeared in such colonies.

\section{RESULTS AND DISCUSSION}

From 25 colonies fed with virus suspensions, 3 colonies developed severe symptoms of the disease and were destroyed. The remaining 22 colonies showed typical symptoms of the disease, were reared through 5 generations to test resistance against the disease, and each generation was fed with the freshly purified suspension in sugar syrup. The typical symptoms of the present disease were similar to those reported in $A$ mellifera from Europe and North America (Gochnauer, 1978). Simultaneously, control colonies (5) were fed with pure sugar syrup during each set of experiment/generation, but no symptoms of the disease appeared within 4-15 d after feeding. 


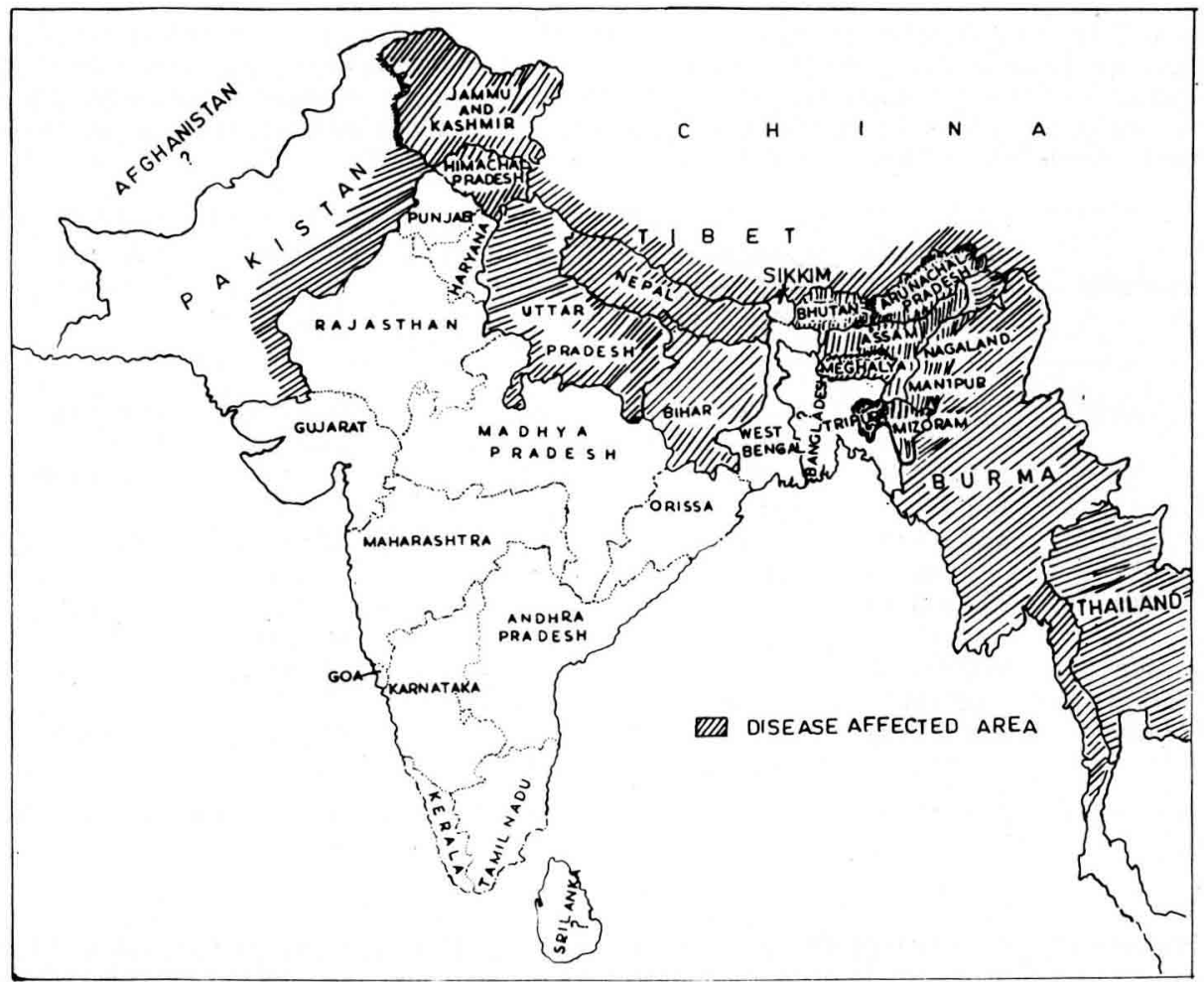

Fig 1. Distribution of Thai Sacbrood Virus disease in Southeast Asia.

When the symptoms of the disease appeared, they appeared within 4-10 d after feeding the virus suspension. Such symptoms appeared earlier in parent (mother) colonies than in subsequent generations (table I). This means that larvae ingested the virus upon hatching from the egg (d 3) and died after being sealed in its cell (d8), and as a result, dead brood (serologically confirmed TSBV) is always observed in sealed cells with perforated cappings. In addition, the percentage of affected brood (sealed-perforated) was greater in parent than in daughter colonies, and a continuous decrease in infection was observed in subsequent generations (table I).
In the present investigation, recovery from infection was observed within $30 \mathrm{~d}$ after the appearance of disease in the colonies. Parent colonies took longer to recover from infection than daughter colonies (table 1). Similarly, percentage reduction in prolificness in the virus-fed colonies decreased from 40 to $7 \%$ from parent to 5 th generation, as compared to respective colonies before feeding (table I).

In parent colonies, abnormal behaviour such as failure to cover brood by nurse bees, tendency to abscond, increased aggressiveness and reduced ability to clean out dead brood was observed, but in subsequent generations, there was gradual 
Table I. The test of resistance against the Thai Sacbrood Virus disease in A cerana. Each mean value represents an average of 22 colonies. "Total brood area in the test colonies varied from 1300$2350 \mathrm{~cm}^{2}$ and having 4 brood cells per $\mathrm{cm}^{2}$. ** Abnormal behaviour : no coverage of diseased brood, frequent tendency to abscond, increased aggressiveness and less efficiency to clean out the dead brood. Figures in parenthesis indicate range of variation.

$\begin{array}{cccccc}\text { Generation } & \begin{array}{c}\text { Appearance } \\ \text { of symptoms } \\ (d)\end{array} & \begin{array}{c}\text { Degree of } \\ \text { infection in } \\ \text { brood (\%) }\end{array} & \begin{array}{c}\text { Percentage } \\ \text { of reduction } \\ \text { in fecundity }\end{array} & \begin{array}{c}\text { Recovery } \\ \text { period } \\ \text { (d) }\end{array} & \begin{array}{c}\text { Behaviour } \\ \text { of colony }\end{array}\end{array}$

\begin{tabular}{|c|c|c|c|c|c|}
\hline Parent & $3.82 \pm 0.02$ & 50 & 40 & $29.82 \pm 0.29$ & abnormal"** \\
\hline 1st & $\begin{array}{c}(3-5) \\
5.01 \pm 0.10 \\
(4-7)\end{array}$ & $\begin{array}{c}(40-60) \\
20 \\
(16-28)\end{array}$ & $\begin{array}{c}(38-42) \\
30 \\
(27-34)\end{array}$ & $\begin{array}{c}(28-30) \\
25.00 \pm 0.23 \\
(24-27)\end{array}$ & near normal \\
\hline 2nd & $\begin{array}{c}4.20 \pm 0.03 \\
(4-6)\end{array}$ & $\begin{array}{c}10 \\
(8-13)\end{array}$ & $\begin{array}{c}22 \\
(19-26)\end{array}$ & $\begin{array}{c}23.10 \pm 0.17 \\
(21-25)\end{array}$ & near normal \\
\hline 3rd & $\begin{array}{c}7.00 \pm 0.08 \\
(5-9)\end{array}$ & $\begin{array}{c}5 \\
(2-7)\end{array}$ & $\begin{array}{c}15 \\
(11-19)\end{array}$ & $\begin{array}{c}20.41 \pm 0.14 \\
(18-22)\end{array}$ & normal \\
\hline 4th & $\begin{array}{c}9.90 \pm 0.13 \\
(8-10)\end{array}$ & $\begin{array}{c}5 \\
(2-6)\end{array}$ & $\begin{array}{c}13 \\
(11-15)\end{array}$ & $\begin{array}{c}16.25 \pm 0.19 \\
(15-18)\end{array}$ & normal \\
\hline 5th & $\begin{array}{c}7.95 \pm 0.09 \\
(7-9)\end{array}$ & $\begin{array}{c}4 \\
(3-5)\end{array}$ & $\begin{array}{c}7 \\
(3-11)\end{array}$ & $\begin{array}{c}15.09 \pm 0.11 \\
(12-19)\end{array}$ & normal \\
\hline
\end{tabular}

improvement and colonies showed normal behaviour. No disease symptoms were observed in control $A$ cerana and virus-fed $A$ mellifera colonies.

These results suggest that some mechanism of resistance to Thai Sacbrood Virus disease exists in $A$ cerana. In nature, this disease had a 4-year cycle and, after this period, surviving colonies began to multiply in a normal way. For example, in Himachal Pradesh (India), this disease was observed from 1983 to $1986 / 87$. After this period, all the surviving colonies are now multiplying and about $25 \%$ of the normal population has been restored during the last 2 years.

\section{ACKNOWLEDGMENTS}

We wish to thank Dr BV Ball, Rothamsted, Experimental Station, England for supplying anti- sera and identifying the present isolate. Thanks also go to the Indian Council of Agricultural Research, New Delhi (India) for the financial grant.

Résumé - Le couvain sacciforme thaï, virose de l'abeille Apis cerana. La virose du couvain sacciforme thaï chez Apis cerana est apparue pour la première fois en Thaillande en 1976. Depuis lors, cette maladie s'est répandue dans plusieurs autres pays asiatiques (fig 1) et a provoqué des pertes économiques sévères pour l'indus. trie apicole. Les colonies qui ont guéri du couvain sacciforme Thaï ont reçu en nourrissement du sirop de sucre à $50 \%$ renfermant des suspensions de virus fraîchement purifiées $(1 / 200 \mathrm{~V} / \mathrm{V})$ et ont été élevées sur 5 générations. Des reines sœurs vierges produites par les colonies témoins se sont accouplées, dans un rucher de fécondation isolé, avec des mâles provenant de colonies qui présentaient 
aussi une résistance naturelle. Des colonies nourries uniquement au sirop de sucre ont servi de témoins.

Les symptômes de la maladie sont apparus entre 4 et $10 \mathrm{j}$ après l'infection expérimentale des colonies et se sont manifestés plus tôt chez les colonies parentales que chez les générations suivantes. Le degré d'infection était donc plus élevé chez les générations parentales que chez les descendantes (tableau I). Les colonies parentales ont mis plus de temps à se rétablir que les descendantes. On a observé de la même façon une diminution de la fécondité de $40 \%$ chez les parents à $7 \%$ chez la $5^{\circ}$ génération, par rapport aux colonies avant l'infection expérimentale.

Les colonies parentales ont montré un comportement anormal, tel que absence de soin au couvain par les nourrices, tendance accrue à la désertion, agressivité accrue et activité réduite de nettoyage des cellules, alors que les colonies-filles des générations suivantes se sont comportées normalement. Aucun symptôme de la maladie n'a été observé chez les colonies d'A mellifica après nourrissement avec du sirop et la solution de virus. Dans la nature, cette maladie a un cycle de 4 années; après cette période les colonies survivantes se développent à nouveau normalement.

\section{Apis cerana / couvain sacciforme thaï / virose}

\section{Zusammenfassung - Die Thai Sack-} brutvirus-Krankheit bei Apis cerana. Die Thai Sackbrutvirus-Krankheit bei Apis cerana trat erstmals in Thailand im Jahre 1976 auf. Seit damals hat sich diese Krankheit über mehrere asiatische Länder verbreitet (Abb 1) und in der Bienenwirtschaft große ökonomische Schäden verursacht. Völker aus den $5 \%$ des
Bestandes, die sich von der Thai Sackbrut-Seuche erholt hatten, wurden mit einer frisch gereinigten Virus-Suspension (1:200 V/N) in Zuckersirup gefüttert und durch fünf Generationen weitergezüchtet. Junge Tochterköniginnen der Versuchsvölker wurden auf einem isolierten Paarungsplatz mit Drohnen aus Völkern zur Paarung gebracht, die ebenfalls eine natürliche Resistenz zeigten. Als Kontrolle dienten Völker, die nur mit Zuckersirup gefüttert worden waren.

Die Krankheitssymptome traten 4-10 Tage nach der Fütterung mit Virus-Sirup auf, und zwar bei der Elterngeneration früher als bei den nachfolgenden Generationen. Ebenso war der Prozentsatz der Infektion bei der Elterngeneration höher als bei den nachfolgenden (Tabelle I). Auch die Erholung von der Infektion dauerte bei den Völkern der Elterngeneration länger als bei den Tochtervölkern. Im Vergleich zu den Völkern vor der experimentellen Infektion sank der Rückgang der Fruchtbarkeit stetig von $40 \%$ zu Beginn auf $7 \%$ in der fünften Generation.

Die Elternvölker zeigten abnormales Verhalten wie fehlende Brutdeckelung durch die Pflegebienen, erhöhte Neigung zum Ausziehen, gesteigerte Stechlust und mangelhaften Putztrieb; die Tochtervölker der folgenden Generationen verhielten sich hingegen normal.

Bei Völkern von $A$ mellifera waren nach Verabreichung der Virus-Lösung keine Krankheitssymptome zu beobachten. Die Beobachtung des Krankheitsverlaufes im Lande ergab einen Vierjahreszyklus; nach dieser Periode begannen die überlebenden Völker, sich wieder normal zu vermehren.

Apis cerana / Thai Sackbrutvirus / Viruskrankheit / Sackbrut 


\section{REFERENCES}

Bailey L, Gibbs AJ, Woods RD (1964) Sacbrood virus of the larvae of honeybee (Apis mellifera L). Virology 23, 425-429

Bailey L, Carpenter JM, Woods RD (1982) A strain of sacbrood virus from Apis cerana. $J$ Invertebr Pathol 39, 264-265

Gochnauer TA (1978) Viruses and rickettsae. In: Honeybee Pests, Predators and Diseas- es. (Morse RA, ed) Cornell University Press, Ithaca, USA, 23-42

Rana BS, Garg ID, Khurana SM Paul, Verma LR, Agrawal HO (1986) Thai Sacbrood Virus of honeybees (Apis cerana indica F) in Northwest Himalayas. Indian J Virol 2, 127-131

Rana BS, Garg ID, Khurana SM Paul, Ball BV, Verma LR, Agrawal HO (1987) Sacbrood Virus disease in Apis cerana indica $\mathrm{F}$ in Southeast Asia. In: Chemistry and Biology of Social Insects (Eder J, Rembold H, eds) Munchen, 640-641 